\title{
Botryosphaeria-related dieback and control investigated in noncoastal California grapevines
}

by Lynn Epstein, Sukhwinder Kaur

and Jean S. VanderGheynst

Dieback, or "dead arm," in noncoastal California grapevines is most commonly caused by Botryosphaeria spp. Using Koch's postulates, we demonstrated that isolates of $\mathrm{B}$. obtusa are pathogenic on grapevines. We initiated studies to investigate the life cycle of $\mathrm{B}$. obtusa and ways to control it with cultural practices. Fungal spores disseminated by rainstorms were collected in traps in an Arbuckle vineyard from December 2006 through spring 2007. The data suggests that B. obtusa was rain-disseminated throughout winter and spring, and that pycnidia on deadwood in the vines is a major source of inoculum for new infections. Transmission may also be possible via vegetative propagation, pruning shears and insects. Durable latex paints were investigated for protecting pruning and surgical wounds; a self-priming latex paint was shown to be an effective barrier and was nonphytotoxic.
Trunk and cordon cankers that cause
vine dieback are serious economic problems in vines 12 years and older. Vines are infected, at least primarily, through pruning wounds. Historically, dieback in California vineyards was attributed to the fungus Eutypa lata, but many of the vines, particularly in the Sacramento and San Joaquin valleys, are actually infected by fungi in the genus Botryosphaeria (Urbez-Torres et al 2006); cankers caused by Botryosphaeria spp. are called "Bot canker."

\section{Signs of disease on grapevines}

Between fall 2004 and spring 2007, we monitored 'Zinfandel' grapevines in Arbuckle, Calif., in an approximately 18-year-old vineyard with many dead spurs and cordons (arms of a grapevine). Our sampling included the extensive dissection of 36 vines in decline. There were two predominant signs of disease in woody tissue: a brownish, often wedge-shaped necrosis (dead tissue) in cross-sections of cankered regions, and dark brown to blackish streaks in longitudinal sections of wood adjacent to pruning wounds. B. obtusa, identified by a combination of microscopy and DNA sequencing of a portion of the ribosomal DNA (called ITS), was routinely isolated from the margins of cankers in woody tissue in all parts of the vines. B. dothidea, B. stevensii and $E$. lata were also occasionally isolated.

Except for a loss of vigor in shoots adjacent to cankered regions, the vines were relatively free of foliar symptoms. Nonetheless, in springtime some vines with multiple dead spurs had de-

formed, chlorotic (yellow) leaves consistent with symptoms of Eutypa dieback. In all 21 vines with foliar symptoms sampled, only B. obtusa was isolated from the margins of discolored woody tissue.

B. obtusa pycnidia were observed, generally infrequently and at low density, on the surface of completely dead wood on vines. (Pycnidia are flaskshaped structures that contain conidia, which are asexual spores.) In contrast, pycnidia were observed frequently on prunings and detached wood on the vineyard floor. Individual pycnidia are black and approximately 0.01 inch $(0.25$ millimeter) in diameter. They are generally aggregated but sometimes separate. When first formed, the pycnidia are submerged in wood, but as they mature they erupt above the trunk sur-
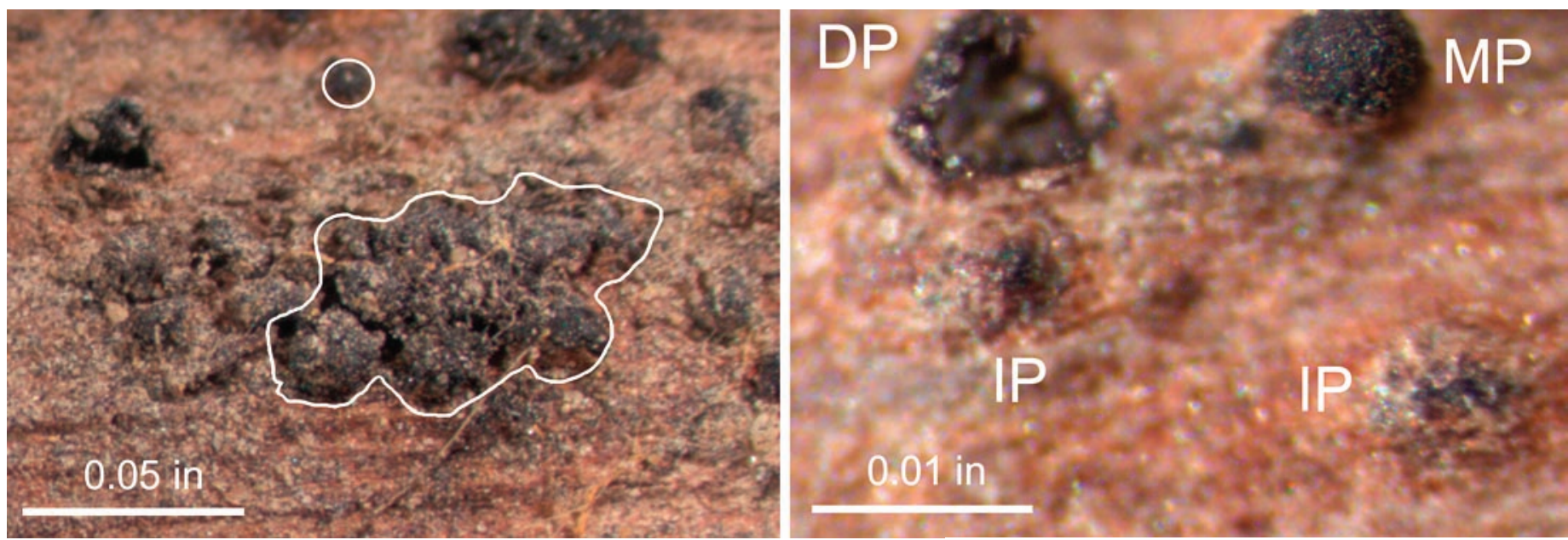

Pycnidia of Botryosphaeria obtusa form on prunings on the vineyard floor. Left, B. obtusa pycnidia are primarily clustered in aggregates (white outline) with some separate individual pycnidia (circle). Right, immature pycnidium (IP) are still partially buried in the plant tissue; mature pycnidium (MP) before spore release; and discharged pycnidium (DP). Microscopic examination of spores is required to identify pycnidia as B. obtusa rather than other Botryosphaeria spp. 


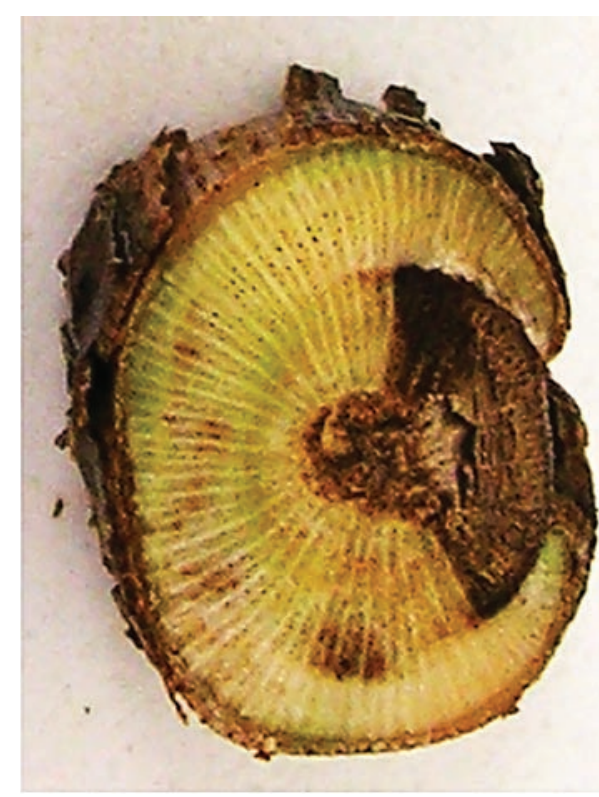

In a pathogenicity test, Botryosphaeria obtusa caused a wedge-shaped lesion.

face. After conidia are released during rainy weather and disseminated via wind-blown rain, the empty pycnidial cavities remain on the plant surface. B. obtusa pycnidia were never observed on grape berries, and no sexual spores of either Botryosphaeria spp. or E. lata were ever observed.

\section{Pathogenicity of $B$. obtusa}

When we started our work, the literature was unclear on whether B. obtusa isolates are pathogenic or saprophytic (living on dead tissue). To test for pathogenicity, own-rooted 'Cabernet Sauvignon' with stems approximately 0.7 inch in diameter were inoculated in the greenhouse with a disc of fungal mycelium (a mass of fungal hyphae) into a wound 5 inches above the soil. After 1 year the plants were examined, Koch's postulates were completed and the experiment was repeated with similar results. (Koch's postulates are a process that allows one to conclude that a particular organism causes a particular disease.)

The greenhouse pathogenicity test produced the two major symptoms that we had observed in the field in infected wood: a brownish, wedge-shaped necrosis in a cross-section and brownish
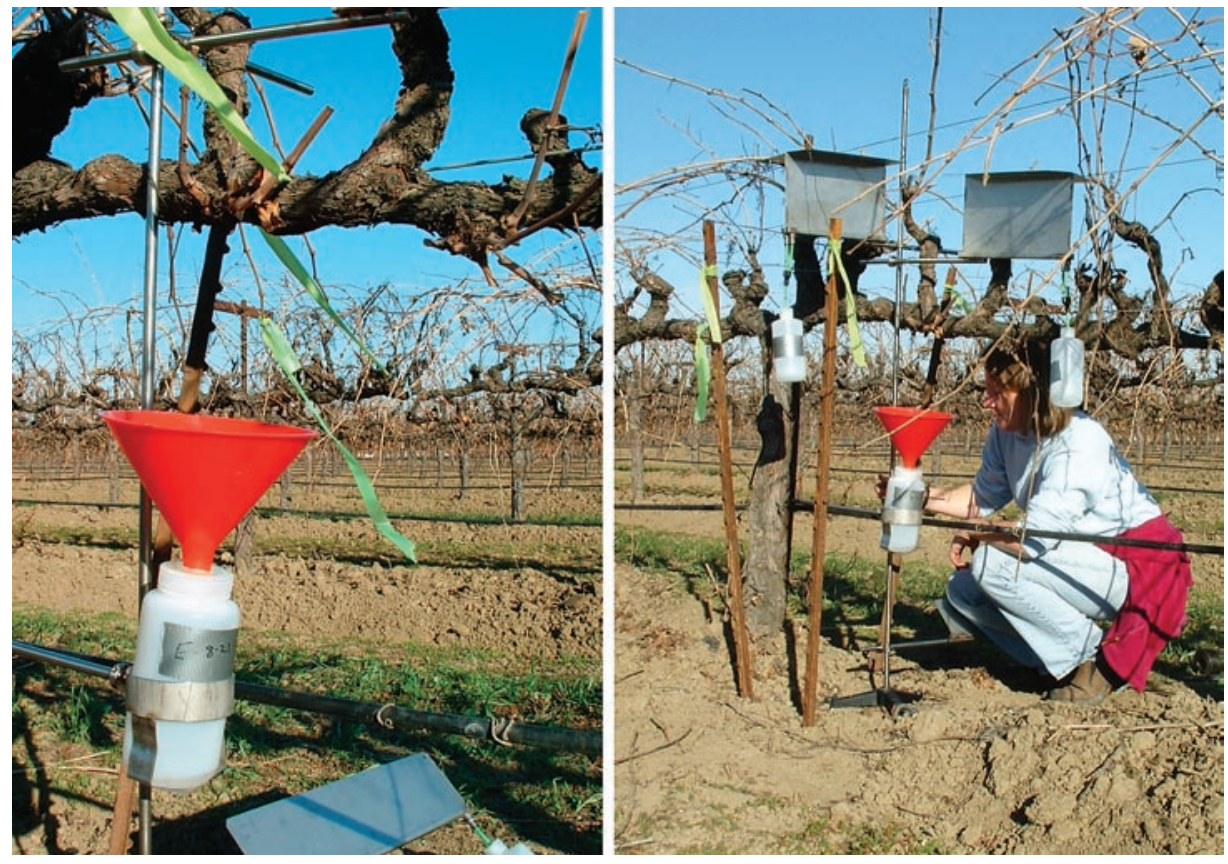

Stands were used to collect fungal spores disseminated in rainstorms. Left, each stand had a funnel under the cordon for estimating available inoculum within the vine, and a plate on the ground ( 2.5 inches high by 20 inches wide) at a $45^{\circ}$ angle to collect splash from debris; right, stands also had two tented plates (8 inches high by 12 inches wide), which were designed to collect wind-blown rain.

to black streaks in a longitudinal section. B. obtusa isolates are pathogenic, and B. obtusa grows more quickly in woody tissue than E. lata (table 1). Our results are in agreement with other reports in which B. obtusa and other Botryosphaeria spp. are identified as important grapevine pathogens (Leavitt and Munnecke 1987; Phillips 1998, 2002; Savocchia et al. 2007; van Niekerk et al. 2004, 2006).

\section{Life cycle of $B$. obtusa in a vineyard}

Spore dissemination. Rain is critical in the life cycle of Botryosphaeria spp. at several stages, including the oozing of conidia out of the pycnidia and then the dissemination of conidia in windblown rain. To monitor spores (the reproductive cells) quantitatively in the vineyard, we used funnels under the vines and constructed plates to collect wind-blown rain. Four replicate spore collectors were placed in each of two fields on Dec. 1, 2006, and removed on May 8, 2007. In order to inhibit germination during collection, the receptacle bottles contained sufficient acetic acid for a final concentration of $12 \%$ or more. Rainwater (figs. 1D-G) and prunings on the ground (figs. 1BC) were collected. After rainwater was filtered through membrane filters with grids, conidia were quantified microscopically at $100 \times$. Weather data were obtained from an on-farm monitoring station and the Nickel's Soil Laboratory in Arbuckle (fig. 1A).

B. obtusa was observed in all rainwater collections; other Botryosphaeria spp. and E. lata were occasionally observed. The most spores were trapped

\begin{tabular}{|c|c|c|}
\hline \multirow[t]{2}{*}{ Inoculation* } & Mean lesion length \pm SEM $†$ & Replicate isolates \\
\hline & inches & no. \\
\hline Botryosphaeria obtusa & $20 \pm 0.8 a$ & 3 \\
\hline Eutypa lata & $14 \pm 0.8 b$ & 2 \\
\hline Mock-inoculated control & $7 \pm 0.8 c$ & 2 \\
\hline \multicolumn{3}{|c|}{$\begin{array}{l}\text { * 'Cabernet Sauvignon' own-rooted cuttings were inoculated on June 2, 2005, and examined } 1 \text { year later. } \\
\text { † Six determinations per isolate and three determinations for each mock-inoculated control, each on a separate vine. } \\
\text { The F-test } P \text { value }=0.0009 \text {. Means followed by the same letter are not significantly different by Tukey's HD, } \alpha=0.05\end{array}$} \\
\hline
\end{tabular}


Fig. 1. Biological and meteorological data from a vineyard in Arbuckle, Calif., between Dec. 2, 2006 (Julian day -30), and May 8, 2007 (Julian day 128) (Julian dates start with 1 on Jan. 1 of each year). (A) Daily precipitation and average air temperature. (B, C) Development and abundance of pycnidia on (B) current prunings (* indicates Dec. 15 pruning); and (C) old prunings and dead wood on the vineyard floor. Prunings were partially submerged in soil and partially exposed; examinations occurred each day that spores were collected. Icons are not shown on examination dates when there were no changes from the previous date. New pycnidia were produced on older prunings and wood in multiple years. (D-G) Means \pm SE of rainstorm-disseminated spores retrieved in various collectors in a field trial with $(D, F)$ surgical removal of deadwood in the vines, painting of all surgical and pruning wounds and sanitation of pruning debris on the ground, and $(E, G)$ without these measures. (D, E) Total number of Botryosphaeria obtusa conidia collected in a 7.25-inch-diameter funnel below the vine. $(F, G)$ Wind-blown $B$. obtusa conidia collected on plates facing north, south, east and west.

in collectors designed for within-vine drip under an infected cordon in a "no sanitation," area; that is, with neither surgical removal of infected wood, painting of pruning wounds or burial of prunings (fig. 1E). Conidial dissemination occurred throughout the pruning period and into the springtime (May 8) in 2007, in apparent contrast to winter-only dissemination of E. lata in California.

Our collection plates for wind-blown rain in the "no sanitation" field (fig. 1G) similarly showed conidial dissemination throughout the December-to-spring observation period. We monitored the development of pycnidia on the current season's prunings from Dec. 15 and on older prunings and wood debris, partly because pycnidia on deadwood in the vine are hard to see and partly because debris on the ground may provide inoculum. Prunings from December 2005 and before, and deadwood on the ground (fig. 1C), primarily released conidia between March 20 and April 14, when it rained on 6 days (fig. 1A). Pycnidia from the current season's prunings matured during 2007, but conidia were not released; release presumably occurred sometime during the 2007-2008 rainy season (fig. 1B). B. obtusa
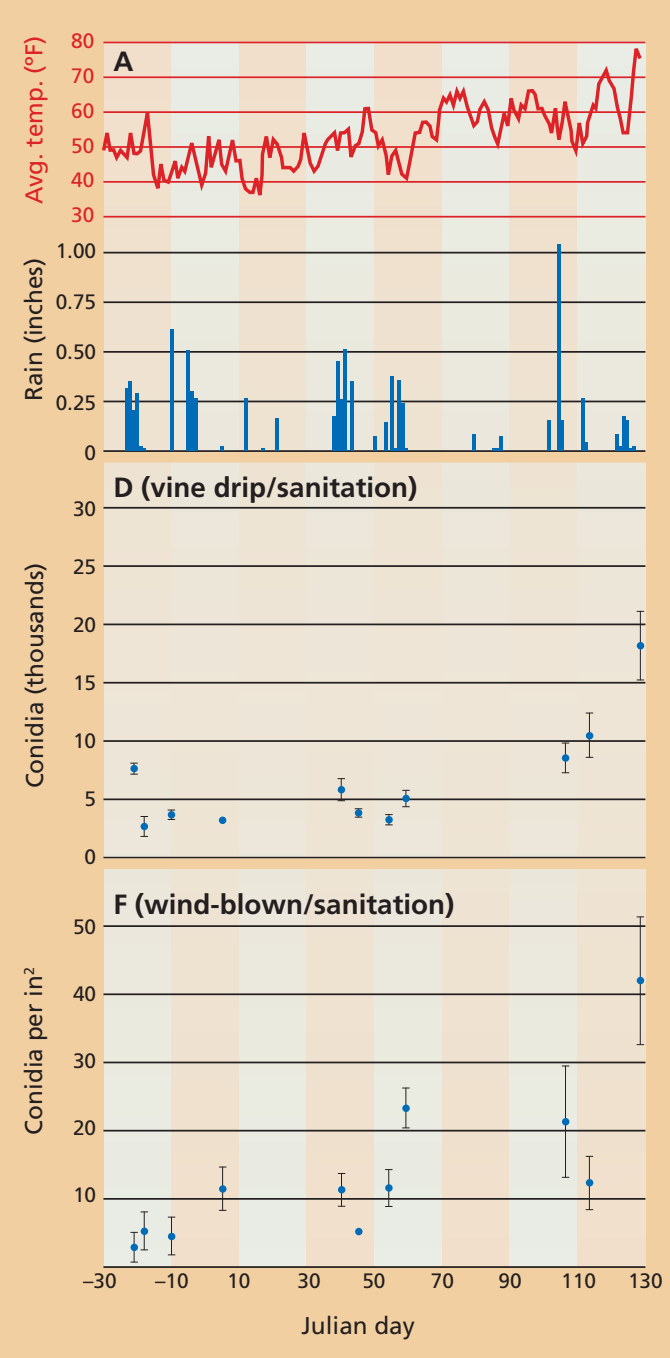

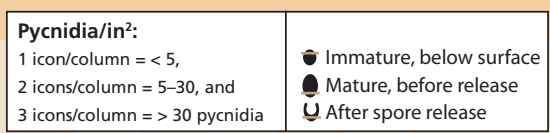

B (current prunings)

* Dec. 15 pruning

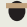

C (old prunings and dead wood)

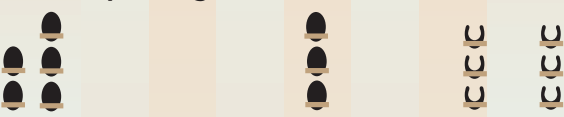

E (vine drip/no sanitation)

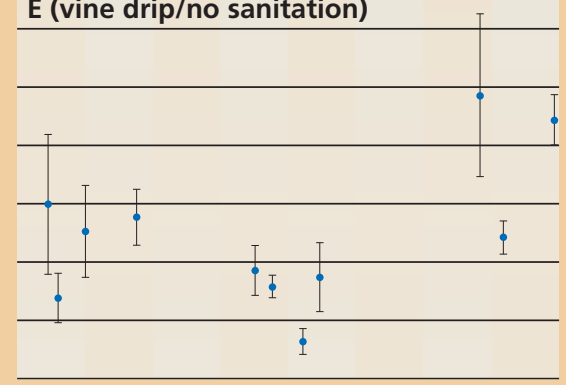

G (wind-blown/no sanitation)

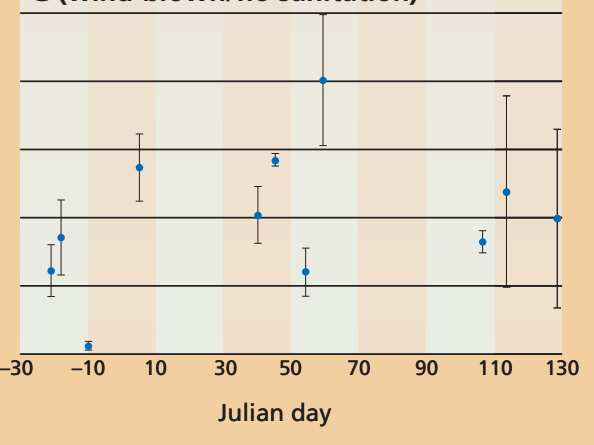

conidia also were collected in angled plates designed to determine if the wind could pick up debris from the soil, although the densities were lower than shown in figs. 1F-G (data not shown).

The sanitation treatment consisted of surgically cutting vines to the trunk, painting surgical and pruning wounds, and burying pruning debris (figs. 1D, 1F). Because there were no pycnidia on these regenerated vines, both the vine drip (fig. 1D) and wind-blown (fig. 1F) are estimates of wind-blown inoculum from outside of the sanitation area. Inoculum concentration in the wind was higher later rather than earlier in the season (fig. 1F, slope of linear regression $P=0.0002$ ).

Infections through wounds. In addition to observing conidial release from pycnidia (fig. 1C) and conidia in all of our traps in springtime (figs. $1 D-G)$, we also had evidence of infections introduced into wounds made when suckers were yanked out of the trunks in springtime. After surgically cutting vines that had at least one infected cordon down to the trunk in December 2004 and allowing them to regenerate for one season, we completely removed 14 vines in December 2005. B. obtusa infections were observed in yanked sucker wounds in 9 of the 14 (64\%) vines. Copes and Hendrix (2004) reported faster conidiation of $B$. obtusa at $64^{\circ} \mathrm{F}$ and $72^{\circ} \mathrm{F}$ than at $54^{\circ} \mathrm{F}$ and $86^{\circ} \mathrm{F}$. Given temperatures in California (fig. $1 \mathrm{~A})$, spring rains may facilitate the most important B. obtusa infection events.

Wood discoloration, a grapevine response to infection, appears to occur approximately 1 year after fungal invasion. Both the patterns of wood discoloration and the recovery of B. obtusa - from incremental segments of shoots from pruning wounds to the shoot terminus - indicate that B. obtusa primarily infects through pruning wounds. In contrast to E. lata, B. obtusa grows into shoots. In infected vines, we isolated 


\section{Vine surgery tested as management strategy for Botryosphaeria}

\author{
by Hal Huffsmith, Robert Abercrombie, \\ Todd Berg and Bernardo Farias
}

$T_{i}^{\text {he }}$ he Sutter Home Vineyard in Arbuckle (Colusa County) was planted in 1988 and 1989 with a high-yielding selection of 'Zinfandel' (for white 'Zinfandel' production) on 'Freedom' and 'Harmony' rootstocks at 7-foot-by-12-foot spacing, with an 18-inch cross-arm. The vineyard encompasses 1,082 planted acres and has historically been pruned sequentially (by block) starting with block 1 around midDecember and finishing block 6 in early February. In 2000, we began noticing erratic budbreak and stunted spring shoot growth in the blocks that were pruned early. These symptoms were visually identified as Eutypa lata infections. When Russell Molyneux with the U.S. Department of Agriculture's Agricultural Research Service in Albany was unable to extract Eutypa metabolites via high-pressure liquid chromatography (HPLC) from cane samples taken at Arbuckle, we began questioning this diagnosis

At about that time, the American Vineyard Foundation (AVF) Eutypa Research Project released a study by Epstein and VanderGheynst indicating that Botryosphaeria (Bot), not Eutypa, was the primary cause of spur dieback in some Central Valley vineyards. This work was later confirmed in vineyards located throughout California (UrbezTorres et al. 2006). In 2004, the Sutter Home Vineyard management group teamed up with Epstein's UC Davis lab to identify and evaluate the organisms causing dieback at Arbuckle and to develop a management strategy to deal with diseased vines.

Epstein, VanderGheynst and Kaur made numerous visits to confirm that Botryosphaeria was the organism causing spur dieback, evaluate potential sources of infection, conduct wound treatment trials and monitor spore release. They observed that deadwood on the cordon and prunings left under the vine (on the berm and between the vine rows) were covered with Botryosphaeria pycnidia and were the likely source of spore release and continuing Botryosphaeria vine infection. The Epstein group initiated a vineyard sanitation trial (see page 161) to quantify Botryosphaeria spores in vineyards with minimal and recommended sanitation. Recommended sanitation includes the removal of deadwood from the vine and either burial or removal of prunings from the vineyard floor. Sanitation appears to be useful for suppressing the initiation of new Botryosphaeria infections. The removal of Botryosphaeria-infected wood from the vine was approached in a couple of ways. The first trial consisted of removing the cordon near the first healthy spur on either side of the stake and switching from spur to cane pruning (see photo A). This approach involved severing the cordons, painting the wounds, disconnecting the cordon wire from the stakes, removing the cordons and cordon wire from the vineyard (burning is an acceptable vine disposal method in Colusa County) and installing a cane wire. This strategy allows for continuous cropping (see photo B) and may be a good way to deal with a mild Botryosphaeria infection.

Severe Botryosphaeria infections may require a different approach. We have successfully left the infected cordons in place and utilized cane pruning with the remaining healthy and productive wood. However, when the per-acre yield per block falls below an economically viable level, severe vine surgery (as opposed to vineyard replanting) will allow vines to stay in the ground and most of the trellis and drip irrigation system to remain intact. The cost for cutting vines above the graft union and about 12 inches from the ground (see photo C), removing and disposing of the upper portion of the vine and the cordon wire, painting the wound, reinstalling a new cordon wire, retraining and tying the vine, repairing trellises and conducting standard farming activities was about $\$ 4.20$ per vine or about $\$ 2,200$ per acre. This method should yield almost a full crop in the second year (see photo D). We are currently evaluating several training practices with the use of either two trunks to reestablish bilateral cordons or quadrilateral cordons, or training the vine for cane pruning (see photo D).

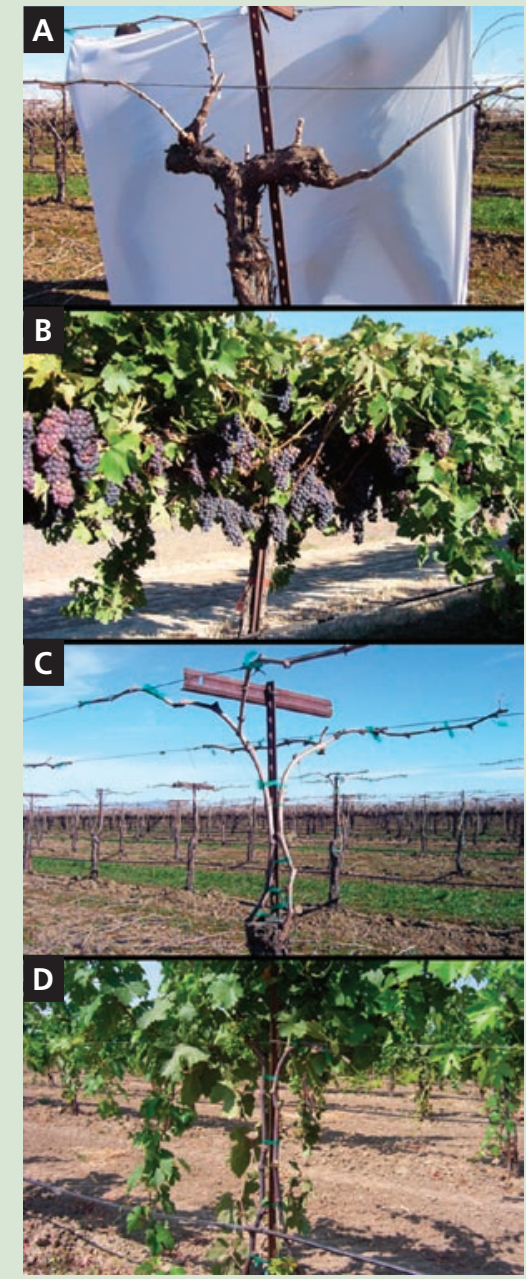

In 'Zinfandel' vines mildly infected with Botryosphaeria obtusa, (A) infected cordon wood was removed, and cane pruning replaced spur pruning and (B) regrowth was treated by removing the cordon portion with dead spurs; in severely infected vines, (C) almost all of the scion was removed and new canes were trained and (D) most of the cordon was removed.

Time will determine if severe vine surgery is successful in reestablishing vineyards infected by Botryosphaeria. RH Phillips vineyard managers initiated this approach to vineyard revitalization several years ago at a planting about 10 miles south of the Arbuckle vineyard with vines apparently suffering from Botryosphaeria infection, and the retrained vines still seem to be vigorous and productive.

H. Huffsmith is Senior Vice President of Vineyard Operations, R. Abercrombie is Vice President of Vineyard Operations, T. Berg is Viticulturist and B. Farias is Arbuckle Vineyard Manager, all with Sutter Home Vineyards, St. Helena. 

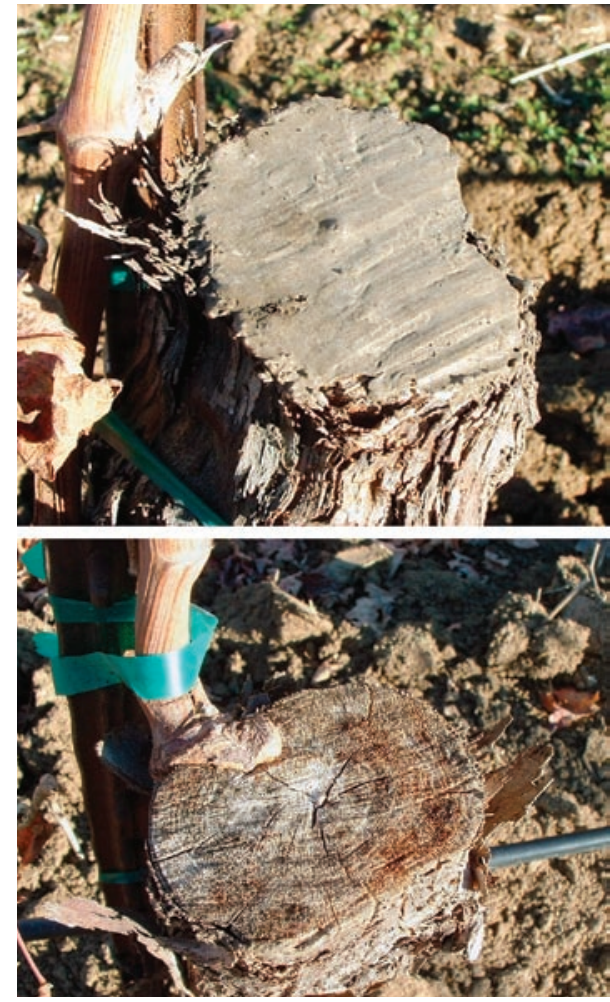

Top, Duration paint is being tested as a treatment for surgical cuts on grapevine trunks; lower, an untreated vine.

B. obtusa in $28 \%$ of asymptomatic shoots and $90 \%$ of symptomatic 1-year-old shoots $(n=54) 3$ inches from the cordon. Symptomatic shoots that were surfacedisinfected and incubated in a humid chamber at $74^{\circ} \mathrm{F}$ for 3 weeks produced B. obtusa pycnidia. Overall, our data are consistent with a life cycle in which $B$. obtusa grows asymptomatically within grapevine shoots and woody tissue. We postulate that damage to the vine occurs primarily by the grapevine's release of self-defense compounds that kill its own cambium.

Other means of spread. Although we postulate that pruning wounds are primarily infected by B. obtusa conidia disseminated in wind-blown rain, some inoculum may also be disseminated by other mechanisms. Pruning cuts through mature pycnidia can release conidia onto shear blades. Even in cases with only mycelium and no spores, transmission is possible via pruning shears. We made pruning cuts on 25 shoots that we knew, retrospectively, were infected. After making the cuts, we wiped the blades onto sterile paper and then cultured the paper; $B$. obtusa was recovered on $24 \%$ of the wipes.

TABLE 2. Two trials in progress on effect of applying Duration paint on pruning and surgical cuts for disease caused by Botryosphaeria spp.

\begin{tabular}{|c|c|c|c|c|}
\hline $\begin{array}{l}\text { Trial no.* } \\
\text { (start date) }\end{array}$ & $\begin{array}{l}\text { Extent of } \\
\text { sanitationt }\end{array}$ & $\begin{array}{l}\text { Painting of surgical } \\
\text { and pruning cuts? }\end{array}$ & $\begin{array}{l}\text { Vines with } \\
\text { weaker growth } \neq\end{array}$ & $\begin{array}{l}\text { Vines with dead } \\
\text { shoots or spurs } ¥\end{array}$ \\
\hline & & & \multicolumn{2}{|l|}{$\ldots \ldots \ldots \ldots \ldots \%$} \\
\hline $1(2005)$ & Minimal & No & 15 & 10 \\
\hline $1(2005)$ & Minimal & Yes & 15 & 6 \\
\hline $2(2006)$ & Recommended & No & 2 & 0 \\
\hline $2(2006)$ & Recommended & Yes & 3 & 0 \\
\hline \multicolumn{5}{|c|}{$\begin{array}{l}\text { * Each trial was designed for categorical data analysis with approximately } 100 \text { replicates in a randomized } \\
\text { complete block design with one replicate per block. No statistical differences }(P=0.05 \text {, Fisher's exact test) } \\
\text { between painted and unpainted vines in each trial as of } 2007 \text {. }\end{array}$} \\
\hline \multicolumn{5}{|c|}{$\begin{array}{l}\text { t Recommended sanitation includes surgical removal of all deadwood within the vine and either burial or } \\
\text { removal of prunings. }\end{array}$} \\
\hline \multicolumn{5}{|c|}{ ‡ Symptoms consistent with infections by B. obtusa were evaluated in October 2007.} \\
\hline
\end{tabular}

In preliminary experiments, in which duct tape covered with the sticky product Tanglefoot was placed over pruning wounds, we recovered rove beetles (Staphilinidae) infested with B. obtusa. We also detected B. obtusa in material that could have been used for vegetative propagation. As indicated above, we isolated $B$. obtusa from asymptomatic shoots. B. obtusa also was isolated from the internal tissue of buds that were surface-disinfected, in $13 \%$ of the buds $(n=60)$ of symptomatic shoots and $9 \%$ of the buds $(n=57)$ from asymptomatic shoots on infected vines.

\section{Strategies for cultural control}

Surgical removal. Several options are available for surgical treatment: (1) the terminus of the affected cordon(s) can be removed, or (2) most of the scion can be removed, retaining only sufficient wood for the regeneration of new canes (see sidebar). In either case, the retention of a mature root system allows rapid regeneration of the scion. The best location for the surgical cut is not always clear. Certainly, cuts should be made below all necrotic and symptomatic tissue. We have isolated B. obtusa in wood up to 4 inches in front of the discolored margin. Although dieback symptoms often appear to be most severe at the ends of the cordons, multiple infection foci can be distributed across the length of asymptomatic portions of the cordon (data not shown). Consequently, we favor cutting down to the trunk.

However, trunks can be infected too. Of the 36 sampled vines, $28(78 \%)$ had infections on the trunk that emanated from wounds on the trunk; wounds were made either when suckers were yanked out or when the mechanical harvester injured the trunk. Moreover, sampling of the wood just above the surgical cut indicated that 10 of the 36 vines (28\%) had infections of B. obtusa at the surgical cut, of which only three had any indication of discoloration. Although in some cases the mechanical harvester appeared to have damaged the vines, we never had evidence that B. obtusa in the trunk per se caused vine debilitation. Based on patterns of discoloration in the trunk, infections of B. obtusa appear to grow primarily toward the base of the stem. While we observed infections in the rootstock, we never observed infections in the roots. A long-term study is needed to determine whether over time, B. obtusa in the trunk leads to a reduction in yield.

Protection with durable paint. We are investigating two strategies for integrated pest management of Bot canker: (1) the protection of surgical wounds and new pruning wounds with a durable paint and (2) the reduction of inoculum sources. Two field trials are in progress to test wound protection (table 2). In 2005, we surveyed paints for use as protectants and selected candidates with the following properties: high elasticity (reduced likelihood for cracking); breathability (presumably less likely to mold under the painted surface); durability to exposure to ultraviolet light and rain; and fungal resistance. After preliminary trials, we selected Duration (Sherwin Williams K34T154) paint, a self-priming exterior latex with an ultradeep base that was stained with 6 ounces of N1 Raw Umber per gallon.

Duration paint forms an impenetrable and stable physical barrier on grapevine surgical cuts and pruning 
wounds. Experimental treatments in which the paint was applied onto pruning wounds and over buds indicated no phytotoxic or inhibitory effects on foliage or bud out-growth (data not shown). The California Department of Pesticide Regulation stated that Duration paint can be used as a physical barrier on grapevines without fungicide registration. Possible advantages of paint over fungicide include that the paint is extremely long-lasting, will not wash off during repeated rains and is not phytotoxic. Nonetheless, painting is laborintensive for a large vineyard. We were not successful in delivering Duration paint using a modified pruner due to Duration's high viscosity, particularly under the cooler weather conditions when pruning is typically done.

In collaboration with Sutter Home Vineyards, Zinfandel vines with dieback symptoms - at least one dead spur - were surgically cut on the trunk approximately 12 inches above the soil in February 2005 (table 2). The surgical cuts were either treated with Duration or not. In the paint-treated vines, all pruning cuts were painted. In 2006, an additional trial with surgically treated vines was started in an area with sanitation. Paint coverage was good in both trials, except when there were heavy rains and sap pushed up a new coating of paint. In this case, paint was reapplied. In both trials, new growth and the establishment of new cordons have been excellent. However, we cannot recommend Duration until data on disease incidence and yield are collected in the next several years. Currently, there is no statistical difference between the incidence of vines with B. obtusa symptoms in paint-protected versus nonprotected vines (table 2).

Inoculum reduction. Our and others' data is consistent with the hypothesis that Botryosphaeria spp. may infect vines via multiple avenues. The presence of B. obtusa pycnidia on deadwood on vines and the collection of conidia in funnels below infected wood suggest that the surgical removal of deadwood should reduce inoculum. Because prunings and deadwood on the vineyard floor can produce large quantities of conidia, we recommend ground sanitation, such as the burial or removal of prunings. Further research is required to determine the contribution of this inoculum to vine infections.

B. obtusa may be transmitted by pruning shears. In a study on the potential transmission of grapevine pathogens in infected propagation material, Aroca et al. (2006) detected Botryosphaeria spp. and Phomopsis along the length of some plants, but mainly at the graft union. Consequently, grafting tools may transmit inoculum. Gimenez-Jaime et al. (2006) identified B. obtusa and other Botryosphaeria spp. in grapevine nurseries. Our isolation of B. obtusa in shoots and buds also suggests that $B$. obtusa might be spread in propagation material.

We monitored rainstorm-disseminated spores over the period when grapevines are pruned, from December to May. Our data indicates that B. obtusa conidia are disseminated during the entire season, including and perhaps especially in spring when temperatures are more conducive for sporulation. Consequently, while later pruning will avoid exposing wounds to early-season rain events and is a worthwhile component of an integrated pest management strategy, it may not provide sufficient control in an infected vineyard.

\section{Research questions}

The development of a cost-effective, sustainable Bot canker management program will require additional

knowledge. Answers to the following questions will be useful: How long are pruning wounds susceptible to infection by Botryosphaeria spp.? What training and pruning strategies minimize the area of susceptible wounds? How does the timing of conidial release vary in different weather conditions? In different vineyards, how important are various modes of pathogen dissemination, and in particular, are Botryosphaeria spp. initially disseminated in vegetatively propagated material that is infected but not symptomatic, and if so, how often? How long are vines productive after major surgery? And do infections occurring below the surgical cut affect the longevity of the vines?

Surgery is being tested in some vineyards as a means to revitalize vines with Bot canker (see sidebar, see page 164). We postulate that a combination of sanitation and surgery will allow sustainable control of Bot canker.

\section{Epstein is Professor of Plant Pathology, and S. Kaur is Staff Research Associate, Department of Plant Pathology, UC Davis; and J.S. Vander- Gheynst is Professor, Biological and Agricultural Engineering, UC Davis. This research was par- tially supported by a grant from the American Vineyard Foundation. We thank Hongyun Guo, Romil Benyamino, Gurdev Dhahan and Burt Vanucci for technical assistance; Frank Zalom for insect identification; and our fantastic collabora- tors and their crew at Sutter Home Vineyards.}

\section{References}

Aroca A, Garcia-Figueres F, Bracamonte L, et al. 2006 Occurrence of fungal pathogens associated with grapevine nurseries and the decline of young vines in Spain. Eur J Plant Pathol 115:195-202.

Copes WE, Hendrix FF Jr. 2004. Effect of temperature on sporulation of Botryosphaeria dothidea, B. obtusa, and B. rhodina. Plant Dis 88:292-6.

Gimenez-Jaime A, Aroca A, Raposo R, et al. 2006. Oc currence of fungal pathogens associated with grapevine nurseries and the decline of young vines in Spain J Phytopathol 154:598-602.

Leavitt GM, Munnecke DE. 1987. The occurrence, distribution, and control of Botryodiplodia theobromae on grapes in California. Phytopathol 77:1690 (abstr.).

Phillips AJL. 1998. Botryosphaeria dothidea and other fungi associated with excoriose and dieback of grapevines in Portugal. Phytopath Z 146:327-32.
Phillips AJL. 2002. Botryosphaeria species associated with diseases of grapevines in Portugal. Phytopathol Mediterr 41:3-18.

Savocchia S, Steel CC, Stodart BJ, Somers A. 2007. Pathogenicity of Botryosphaeria species isolated from declining grapevines in subtropical regions of Eastern Australia. Vitis 46:27-32

Urbez-Torres JR, Leavitt GM, Voegel TM, Gubler WD. 2006. Identification and distribution of Botryosphaeria spp. associated with grapevine cankers in California. Plant Dis 90:1490-503.

Van Niekerk JM, Crous PW, Groenewald JZ, et al. 2004. DNA phylogeny, morphology and pathogenicity of Botryosphaeria species on grapevines. Mycologia 96:781-98.

Van Niekerk JM, Fourie PH, Halleen F, Crous PW. 2006. Botryosphaeria spp. as grapevine trunk disease pathogens. Phytopathol Mediterr 45:S43-S54. 